\title{
Microbial Community Analysis of a Methane-Producing Biocathode in a Bioelectrochemical System
}

\author{
Mieke C. A. A. Van Eerten-Jansen, ${ }^{1}$ Anna B. Veldhoen, ${ }^{1}$ Caroline M. Plugge, \\ Alfons J. M. Stams, ${ }^{2}$ Cees J. N. Buisman, ${ }^{1}$ and Annemiek Ter Heijne ${ }^{1}$ \\ ${ }^{1}$ Sub-Department of Environmental Technology, Wageningen University, Bornse Weilanden 9, 6700 AA Wageningen, The Netherlands \\ ${ }^{2}$ Laboratory of Microbiology, Wageningen University, Dreijenplein 10, $6703 \mathrm{HB}$ Wageningen, The Netherlands
}

Correspondence should be addressed to Annemiek Ter Heijne; annemiek.terheijne@wur.nl

Received 28 May 2013; Revised 5 August 2013; Accepted 19 August 2013

Academic Editor: Largus T. Angenent

Copyright ( 2013 Mieke C. A. A. Van Eerten-Jansen et al. This is an open access article distributed under the Creative Commons Attribution License, which permits unrestricted use, distribution, and reproduction in any medium, provided the original work is properly cited.

\begin{abstract}
A methane-producing biocathode that converts $\mathrm{CO}_{2}$ into methane was studied electrochemically and microbiologically. The biocathode produced methane at a maximum rate of $5.1 \mathrm{~L} \mathrm{CH}_{4} / \mathrm{m}^{2}$ projected cathode per day $\left(1.6 \mathrm{~A} / \mathrm{m}^{2}\right)$ at $-0.7 \mathrm{~V}$ versus NHE cathode potential and $3.0 \mathrm{~L} \mathrm{CH}_{4} / \mathrm{m}^{2}$ projected cathode per day $\left(0.9 \mathrm{~A} / \mathrm{m}^{2}\right)$ at $-0.6 \mathrm{~V}$ versus $\mathrm{NHE}$ cathode potential. The microbial community at the biocathode was dominated by three phylotypes of Archaea and six phylotypes of bacteria. The Archaeal phylotypes were most closely related to Methanobacterium palustre and Methanobacterium aarhusense. Besides methanogenic Archaea, bacteria seemed to be associated with methane production, producing hydrogen as an intermediate. Biomass density varied greatly with part of the carbon electrode covered with a dense biofilm, while only clusters of cells were found on other parts. Based on our results, we discuss how inoculum enrichment and changing operational conditions may help to increase biomass density and to select for microorganisms that produce methane.
\end{abstract}

\section{Introduction}

In bioelectrochemical systems (BES), microorganisms catalyze oxidation and reduction reactions to produce or use electricity. Recently, it has been discovered that microorganisms can accept electrons from an electrode [1] to bioremediate metal and organic contaminants or for microbial electrosynthesis to produce fuels and chemicals. Using microorganisms as catalysts on an electrode instead of chemical catalysts is innovative and sustainable; the microorganisms are self-regenerating and the BES can be operated at ambient conditions (at neutral $\mathrm{pH}$ and low temperature), and low-cost carbon electrodes can be used [2, 3]. Microbial electrosynthesis in BES has been described for the production of, for example, hydrogen [4], hydrogen peroxide [5], caustic [6], acetate and 2-oxobutyrate [7, 8], ethanol [9], ammonium [10], butyrate [11], or caproate and caprylate [12].
Another attractive application of microbial electrosynthesis is the conversion of $\mathrm{CO}_{2}$ into methane [13]. Besides producing carbon-neutral methane, BES can convert excess renewable electricity from sun and wind into methane as an energy carrier [13]. Moreover, the infrastructure for transport, storage and consumption of methane is already in place [13].

To improve the performance of a methane-producing BES, focus so far was mainly on BES design [14-17]. However, another key challenge is understanding the methaneproducing microbial communities in order to improve the methane production rate and energy efficiency [18]. The microbial consortium (types of microorganisms, community composition, and interaction between microorganisms) and the biomass density (the number of microorganisms at a specified electrode surface or reactor volume that take part in these processes) will influence the performance of 
methane-producing biocathodes [18]. Selecting for electrochemically active microorganisms that produce methane and operating the BES under the most favorable conditions for the selected microorganisms may help to further improve the performance of a methane-producing BES [18].

The microbial composition of a methane-producing biocathode using enriched cultures as inoculum is scarcely documented $[8,13]$. Cheng and coworkers obtained an enriched mixed-culture methane-producing biocathode after inoculating the cathode with the effluent of an existing bioanode [13]. Therefore, it was known beforehand that electrochemically active microorganisms would be present in the biofilm. The methane-producing biocathode consisted of an enriched consortium dominated by Methanobacterium palustre, which accounted for $86 \%$ of the total number of cells. A biocathode inoculated with a pure culture of $M$. palustre, however, produced less methane than the mixedculture biocathode [13]. The role of the other detected microbial community members in methane production was not investigated. Marshall and co-workers obtained an enriched mixed-culture methane-producing biocathode after inoculating the cathode with brewery wastewater sludge that was pretreated at $-0.59 \mathrm{~V}$ versus NHE cathode potential and that produced methane at this potential [8]. The microbial community at the methane-producing biocathode consisted of methanogens related to Methanobacterium sp. (>93\%) and Methanobrevibacter ( 5\%) and bacteria related to the Sphingobacteriales WCHB1-69 family (37.7\%), the Spirochaetaceae family (17.4\%), and the Synergistaceae family (11.1\%) [8]. It is possible that the bacteria related to the Sphingobacteriales family catalyzed bioelectrochemical hydrogen production [8], but the role of the other bacteria was not investigated.

Although the microbial community of methane-producing biocathodes has been described before, the possible roles of the detected community members in methane production remain unclear. In this study, the electrochemical performance and microbial community of a mixed-culture methane-producing biocathode were investigated to illuminate the possible role of the detected community members in methane production.

\section{Materials and Methods}

2.1. Electrochemical Cell. A flat plate electrochemical cell (1.24 L total volume) was used with a cathode and anode volume of $0.62 \mathrm{~L}$ each (described in more detail in [19]), using a cation exchange membrane (fumasep FKB, FuMATech GmbH, Germany). Both the anode and cathode were made of graphite felt $(19 \times 19 \mathrm{~cm}$, thickness $3 \mathrm{~mm}$ FMI Composites Ltd., Scotland) having an effective geometric channel surface area of $290 \mathrm{~cm}^{2}$ each. The electrolytes flowed parallel to the electrodes through serpentine flow channels in both the anode and cathode compartments (Figure 1). The anode and cathode compartments were equipped with an $\mathrm{Ag} / \mathrm{AgCl}, 3 \mathrm{M} \mathrm{KCl}$ reference electrode $(+0.205 \mathrm{~V}$ versus NHE; ProSense QiS, The Netherlands). The reference electrode was connected to a glass capillary with a membrane tip that was inserted at the top of the cathode near the outlet

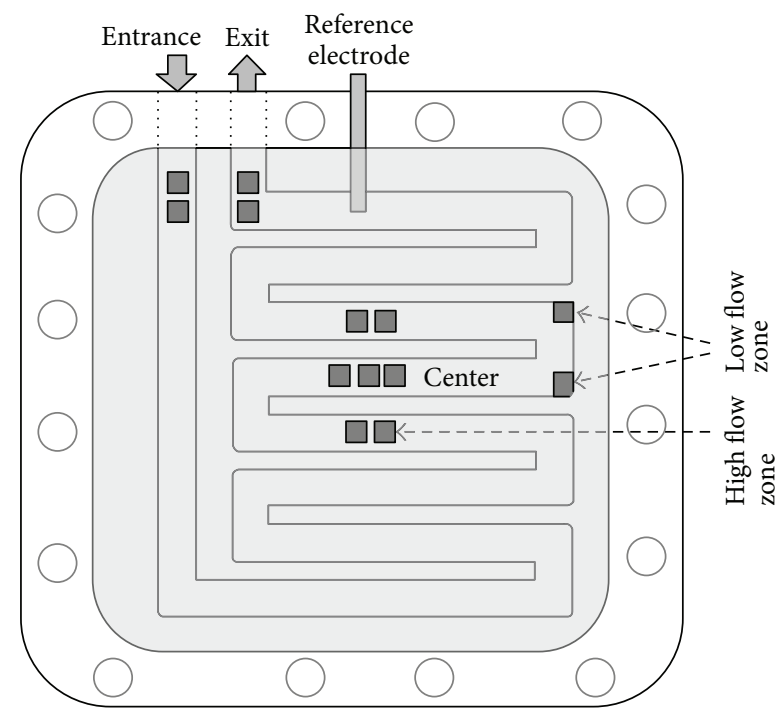

FIGURE 1: Schematic representation of the cathode chamber with the locations of the samples (dark grey squares) used for microbiological analysis. Samples were about $1 \times 1 \mathrm{~cm}^{2}$. The high flow zone is where the cathode was in contact with the straight part of the flow channels, while the low flow zone is where the cathode was located in a dead zone. The graphite felt electrode (light grey) was placed between two supportive flow channel plates. The total projected surface area of cathode was $361 \mathrm{~cm}^{2}$, while the effective geometric channel surface area was $290 \mathrm{~cm}^{2}$.

(the glass capillary was positioned $5 \mathrm{~mm}$ from the graphite felt; Figure 1). The cathode headspace was connected to a gas flow meter (MilliGascounter, Ritter, Germany) via an injection port containing a septum. The cathode headspace volume was on average of $750 \pm 250 \mathrm{~mL}$ and varied due to the batch-wise feeding of the catholyte. The experiment was performed in a temperature controlled chamber at $30^{\circ} \mathrm{C}$.

2.2. Electrolytes and Microorganisms. The anolyte consisted of $50 \mathrm{mM}$ potassium hexacyanoferrate(II) in deionized water. The anolyte was recirculated over a $10 \mathrm{~L}$ vessel at $1.5 \mathrm{~mL} / \mathrm{s}$ and replenished on days 16,28 , and 49 to avoid depletion of electron donor. The catholyte consisted of $20 \mathrm{mM}$ potassium phosphate buffer, macronutrients $\left(280 \mathrm{mg} / \mathrm{L} \mathrm{NH}_{4} \mathrm{Cl}, 5.7 \mathrm{mg} / \mathrm{L} \mathrm{CaCl} 2,10 \mathrm{mg} / \mathrm{L} \mathrm{MgSO}{ }_{4} \cdot 7 \mathrm{H}_{2} \mathrm{O}\right.$, and $90 \mathrm{mg} / \mathrm{L} \mathrm{MgCl}_{2} \cdot 6 \mathrm{H}_{2} \mathrm{O}$ ), $1 \mathrm{~mL} / \mathrm{L}$ of a micronutrients solution, and $1 \mathrm{~mL} / \mathrm{L}$ of a vitamin solution as described in [20]. To the catholyte $5 \mathrm{~g} / \mathrm{L} \mathrm{NaHCO}_{3}$ was added as a carbon source, since at the operating conditions of $\mathrm{pH} 7, \mathrm{CO}_{2}$ is predominantly present as bicarbonate. The catholyte was recirculated over a $0.5 \mathrm{~L}$ vessel at $1.5 \mathrm{~mL} / \mathrm{s}$. To avoid depletion of substrate, every two to three days $250-350 \mathrm{~mL}$ catholyte in the electrochemical cell was replaced by $250 \mathrm{~mL}$ fresh catholyte under continuous flushing with nitrogen gas. The cathode was inoculated with 5 grams of anaerobic sludge obtained from an upflow anaerobic sludge blanket reactor treating distillery wastewater (Royal Nedalco, The Netherlands). After inoculation, the system was flushed with pure nitrogen (>99.9992\%) for 30 minutes before applying a cell voltage and starting the experiment. The $\mathrm{pH}$ of the catholyte 
was controlled at $\mathrm{pH} 7 \pm 0.1$ by a $\mathrm{pH}$ controller (Liquisys $\mathrm{M}$ CPM 253, Endress + Hauser, Switzerland) using $1 \mathrm{M} \mathrm{HCl}$.

2.3. Electrochemical Cell Operation. The electrochemical cell was connected to a potentiostat (MCP94, Bank Elektronik Intelligent Controls GmbH, Germany) using as a twoelectrode configuration where the cathode was connected to the work electrode and the anode was connected to both the counter electrode and the reference electrode. From the beginning, the electrochemical cell was operated at cathode potential $-0.7 \mathrm{~V}$ versus $\mathrm{NHE}$, as at this cathode potential methane can be both produced directly or via hydrogen as an intermediate [21]. From the moment that only methane and no hydrogen were detected in the cathode gas phase (day 24), the cathode potential was changed to $-0.6 \mathrm{~V}$ versus NHE to decrease the energy input of the electrochemical cell. The cathode potential was controlled via the cell voltage as described in [17]. The cell voltage was adjusted when the cathode potential deviated $>20 \mathrm{mV}$ from the desired cathode potential. The experiment was terminated on day 57 , due to leakages at the anode.

2.4. Analysis and Calculations. The electrochemical cell was connected to a PC via a Fieldpoint FP-AI-110 module (National Instruments, USA), and every 60 seconds cell voltage, current, and cathode and anode potential were measured using LabVIEW 7.1 (National Instruments, USA). Daily averages were calculated and reported throughout this paper.

Gas composition of the cathode gas phase was measured on days $0,12,24,33,51$, and 57 with two different gas chromatographs to measure methane, hydrogen, and oxygen. Gas samples were taken with a $100 \mu \mathrm{L}$ gastight syringe (Hamilton, USA) from the injection port near the gas flow meter. Hydrogen was measured with an HP 5890A gas chromatograph by injecting $100 \mu \mathrm{L}$ of gas-sample on a molsieve column $(30 \mathrm{~m} \times 0.53 \mathrm{~mm} \times 0.25 \mathrm{~mm})$ with thermal conductivity detection (TCD). The oven temperature was $40^{\circ} \mathrm{C}$, the injection gate was $110^{\circ} \mathrm{C}$, and the TCD was $150^{\circ} \mathrm{C}$. The carrier gas was argon and had a flow rate of $20 \mathrm{~mL} / \mathrm{min}$. Methane and oxygen were measured with a Finsons Instruments GC 8340 gas chromatograph. Gas $(100 \mu \mathrm{L})$ was split $(1: 1)$ over a molsieve column $(30 \mathrm{~m} \times$ $0.53 \mathrm{~mm} \times 25 \mathrm{~mm})$ and a PoraBOND Q column $(25 \mathrm{~m} \times$ $0.53 \mathrm{~mm} \times 10 \mathrm{~mm}$ ). The oven temperature was $40^{\circ} \mathrm{C}$, injection gate was $110^{\circ} \mathrm{C}$, and the TCD was $90^{\circ} \mathrm{C}$. The carrier gas was helium and had a flow rate of $45 \mathrm{~mL} / \mathrm{min}$. Gas composition was measured immediately after replenishing the catholyte and just before the next catholyte replenishment. The time between catholyte replenishments was two to three days. Gas production was continuously measured with a gas flow meter (Milligascounter, Ritter, Germany). Methane production was calculated using the total gas production and the measured methane fractions, as in [22].

To compare methane production rates with those reported in the literature, all rates were calculated at standard temperature and pressure (STP, $273.15 \mathrm{~K}$ and $1 \mathrm{~atm}$ ) and with respect to the projected cathode surface area (1) or total reactor volume (2) according to

$$
\begin{aligned}
r_{\mathrm{CH}_{4}}^{\mathrm{STP}} & =\frac{V_{\mathrm{CH}_{4, t}} \cdot T_{\mathrm{STP}} \cdot p}{A_{\mathrm{Cat}} \cdot \Delta t \cdot T \cdot p_{\mathrm{STP}}}, \\
r_{\mathrm{CH}_{4}}^{\mathrm{STP}} & =\frac{V_{\mathrm{CH}_{4, t}} \cdot T_{\mathrm{STP}} \cdot p}{V_{\text {reactor }} \cdot \Delta t \cdot T \cdot p_{\mathrm{STP}}},
\end{aligned}
$$

where $r_{\mathrm{CH}_{4}}^{\mathrm{STP}}$ is the methane production rate at STP $\left(\mathrm{L} \mathrm{CH}_{4} / \mathrm{m}^{2}\right.$ projected cathode per day or $\mathrm{L} \mathrm{CH}_{4} / \mathrm{L}$ reactor per day), $V_{\mathrm{CH}_{4}, t}$ is the cumulative methane gas production $(\mathrm{L})$ on sample time $t, A_{\text {cat }}$ is the projected cathode surface area $\left(0.029 \mathrm{~m}^{2}\right)$, $V_{\text {reactor }}$ is the total reactor volume $(1.24 \mathrm{~L}), t$ is the time $(\mathrm{s})$, $T$ is the temperature used in this study $(303 \mathrm{~K}), p$ is the pressure used in this study $(1.005 \mathrm{~atm})$, and $T_{\mathrm{STP}}$ and $p_{\mathrm{STP}}$ are the temperature and pressure at STP, $273.15 \mathrm{~K}$ and $1 \mathrm{~atm}$, respectively. Cathodic electron efficiency, the efficiency of capturing the electrons from the electric current in methane, was calculated as in [17]:

$$
\eta_{\mathrm{CE}}=\frac{V_{\mathrm{CH}_{4}, t} \cdot F \cdot n}{V_{m} \cdot \int_{t=0}^{t} I d t} \cdot 100 \%,
$$

where $F$ is faraday constant $\left(96485 \mathrm{C} /\right.$ mole $\left.^{-}\right), n$ is the moles of electrons per mole of methane ( 8 mole $\left.\mathrm{e}^{-} / \mathrm{mole}^{\mathrm{CH}} \mathrm{H}_{4}\right), V_{m}$ is the molar volume $(22.7 \mathrm{~L} / \mathrm{mole}$ at $273.15 \mathrm{~K}$ and $1 \mathrm{~atm}), I$ is the current $(\mathrm{A})$, and $t$ is the time (s).

2.5. Microbiological Characterization of the Methane-Producing Biocathode. At the end of the experiment (day 57), the cathode was cut into samples of about $1 \times 1 \mathrm{~cm}^{2}$. These samples were used to characterize the microorganisms that had developed at the methane-producing biocathode. The samples were taken at three different locations at the cathode: where the catholyte entered the electrochemical cell (referred to as "entrance"), the center of the cathode (referred to as "center"), and where the catholyte left the electrochemical cell (referred to as "exit"). The locations of the samples are indicated in Figure 1.

The microorganisms present at the biocathode were identified using the molecular techniques described below. The amount of volatile suspended solids (VSS) was quantified using the modified Hartree-Lowry protein analysis. The morphology and distribution of microorganisms at the biocathode were visualized by fluorescence microscopy and scanning electron microscopy.

2.5.1. Microbial Community Analysis. Community analysis was performed at Nadicom GmbH Microbiology Services (Germany). Total genomic DNA was extracted from the $1 \times$ $1 \mathrm{~cm}^{2}$ cathode sample taken in the high flow zone (Figure 1) of the center of the biocathode using the DNA extraction kit from AppliChem (Germany) according to manufacturer's instructions. PCR amplification of the bacterial 16S rRNA gene was performed corresponding to standard operating procedure (SOP) AD-01, using primers 27f and 1492r [23]. PCR protocols for amplification were initial denaturation 
for 5 minutes at $95^{\circ} \mathrm{C}$, followed by 28 cycles of denaturation (20 seconds at $94^{\circ} \mathrm{C}$ ), annealing $\left(30\right.$ seconds at $55^{\circ} \mathrm{C}$ ), and extension $\left(60\right.$ seconds at $\left.72^{\circ} \mathrm{C}\right)$, followed by a final extension $\left(10\right.$ minutes at $\left.72^{\circ} \mathrm{C}\right)$. The amplicons were stored at $8^{\circ} \mathrm{C}$ until further analysis. For the identification of methanogenic Archaea (indicated as "methanogens" in the rest of the manuscript), PCR was performed corresponding to SOP AD-01-1 [24], using primers Ar109f and Ar907r to amplify archaeal 16S rRNA. PCR protocols for amplification were initial denaturation for 5 minutes at $94^{\circ} \mathrm{C}$, followed by 28 cycles of denaturation ( 60 seconds at $94^{\circ} \mathrm{C}$ ), annealing (60 seconds at $52^{\circ} \mathrm{C}$ ), and extension ( 90 seconds at $72^{\circ} \mathrm{C}$ ), followed by a final extension $\left(6\right.$ minutes at $\left.72^{\circ} \mathrm{C}\right)$ [24]. The samples were stored at $4^{\circ} \mathrm{C}$ until further analysis. Archaeal and bacterial PCR amplicons were purified with the ChargeSwitch PCR Clean-Up Kit (Invitrogen, USA) according to manufacturer's instructions and cloned into E. coli JM109 using the TOPO TA Cloning Kit (Invitrogen, USA). After blue/white screening, positive colonies were transferred to LB medium containing $100 \mu \mathrm{g} / \mathrm{mL}$ ampicillin and were grown overnight at $37^{\circ} \mathrm{C}$. Plasmid DNA was isolated using the PureLink Quick Plasmid Miniprep Kit (Invitrogen, USA) according to the manufacturer's instructions. The PCR product quality was checked by agarose-gel-electrophoresis (1\%) stained with ethidium bromide. PCR products with a size of $1.7 \mathrm{~Kb}$ were screened with a specific digestion using enzyme MSP1. Clones showing a unique band pattern were sequenced via cycle sequencing. The obtained sequences were compared to reference sequences in the NCBI BLAST database (http://blast.ncbi.nlm.nih.gov/). A phylogenetic classification was obtained, together with the degree of similarity to the reference sequences. Sequences retrieved in this study are accessible in the GenBank database under the accession numbers KC821541-KC821549.

2.5.2. Modified Hartree-Lowry Analysis. The modified Hartree-Lowry method was used to determine the protein concentration per $\mathrm{m}^{2}$ of biocathode in order to quantify the biomass density (expressed as volatile suspended solids (VSS) per $\mathrm{m}^{2}$ projected cathode surface area). The modified Hartree-Lowry method was applied to two-entrance samples, two-center samples, and two-exit samples to investigate the effect of location on microbial cell concentration (Figure 1). For all samples, the exact surface area of the sample was measured. Each sample was transferred in a $2 \mathrm{~mL}$ vial, suspended in $1 \mathrm{~mL} 1 \mathrm{M} \mathrm{NaOH}$, and mixed vigorously for 30 seconds to make sure biomass was suspended and not attached to the graphite felt. The vial was left at $46^{\circ} \mathrm{C}$ for $35 \mathrm{~min}$ to hydrolyze the cells, and the sample was subsequently neutralized with $1 \mathrm{~mL} 1 \mathrm{M} \mathrm{HCl}$. The samples were once again mixed vigorously for 30 seconds. The suspension was filtered over a $2 \mu \mathrm{m}$ filter paper (Whatman $589 / 3$, GE Healthcare, UK) to separate hydrolyzed cells from graphite fibers. To $0.5 \mathrm{~mL}$ filtrate, $2.5 \mathrm{~mL}$ filtered Lowry medium $\left(19.6 \mathrm{~g} / \mathrm{L} \mathrm{Na} \mathrm{CO}_{3}, 0.20 \mathrm{~g} / \mathrm{L} \mathrm{Na} \mathrm{Na}_{6} \mathrm{H}_{5} \mathrm{O}_{7}\right.$, and $0.1 \mathrm{~g} / \mathrm{L} \mathrm{CuSO} \mathrm{Cu}_{4} \cdot 5 \mathrm{H}_{2} \mathrm{O}$ ) was added, and the solution was mixed vigorously. After 15 minutes, $0.25 \mathrm{~mL}$ Folin-Ciocalteu's phenol reagent was added to the solution, and again the solution was mixed vigorously. After 25 minutes, the solution was spectrophotometrically analyzed at $650 \mathrm{~nm}$ (XION 500 spectrophotometer, Hach Lange $\mathrm{GmbH}$ Germany). The biomass density (g VSS $/ \mathrm{m}^{2}$ projected cathode surface area) was calculated according to

$$
\rho_{\mathrm{VSS}}=\frac{C_{\text {protein }} \cdot V_{\text {spec }} \cdot 4}{0.25 \cdot A_{\text {felt }}},
$$

where $C_{\text {protein }}$ is the spectrophotometrically analyzed protein concentration derived from calibration measurements in which bovine serum albumin was used as reference protein $(\mathrm{g} / \mathrm{mL}), V_{\text {spec }}$ is the total sample volume that was spectrophotometrically analyzed $(3.25 \mathrm{~mL}), 4$ is the dilution factor of the original sample, 0.25 is the conversion of g protein to $\mathrm{g}$ VSS, and $A_{\text {felt }}$ is the surface area of the biocathode sample $\left(\mathrm{m}^{2}\right)$.

2.5.3. Fluorescence Microscopy. Methanogenic archaea have a low-potential electron carrier coenzyme $\mathrm{F}_{420}$ that emits a blue-green autofluorescence when exposed to ultraviolet light at a wavelength of $420 \mathrm{~nm}$. Therefore, immediately after dismantling the methane-producing BES (day 57), two samples of the high flow zone of the center of the biocathode (Figure 1) were observed under a UV fluorescence microscope (Leica DMR FC4 microscope with Leica DFC340 FX camera, Germany) with filter cube I3 to identify the presence of active methanogens. The $3 \mathrm{D}$ structure and the $3 \mathrm{~mm}$ thickness of the graphite felt electrode made it impossible to observe the intact biocathode under the UV fluorescence microscope. Therefore, graphite fibers were taken from the graphite felt electrode and were observed under the UV fluorescence microscope.

2.5.4. Scanning Electron Microscopy. Two samples from a low flow zone (where the cathode was located in a dead zone) and two samples of a high flow zone (where the cathode was in contact with the straight part of the flow channels) at the center of the biocathode (Figure 1) were analyzed using scanning electron microscopy. The biocathode samples were fixed for 2 hours in $2.5 \%$ glutaraldehyde in PBS $(130 \mathrm{mM} \mathrm{NaCl}$ in $10 \mathrm{mM}$ phosphate buffer $\mathrm{pH}$ 7.2). After fixation, the samples were washed with PBS for 3 times for 15 minutes per washing step. The samples were dehydrated through a series of ethanol baths of increasing concentrations: $10,25,50,75$, and $90 \%$ $(\mathrm{v} / \mathrm{v}), 20$ minutes each, and finally in $100 \%$ (v/v) ethanol for 30 minutes. The samples were dried in a desiccator and finally sputter coated with a $5 \mathrm{~nm}$ thin gold layer before visualization under high vacuum with a JSM-6480 LV scanning electron microscope (Jeol, Japan) at $10 \mathrm{kV}$ accelerating voltage.

\section{Results and Discussion}

3.1. Performance of the Methane-Producing Biocathode. Current consumption started directly after applying a cathode potential at the start of the experiment. Current density increased to $1.6 \mathrm{~A} / \mathrm{m}^{2}$ projected cathode (day 24, Figure 2(a)). On day 24 , solely methane and no hydrogen were detected in the cathode gas phase, indicating an active methaneproducing biocathode. On day 24 , the cathode potential was 


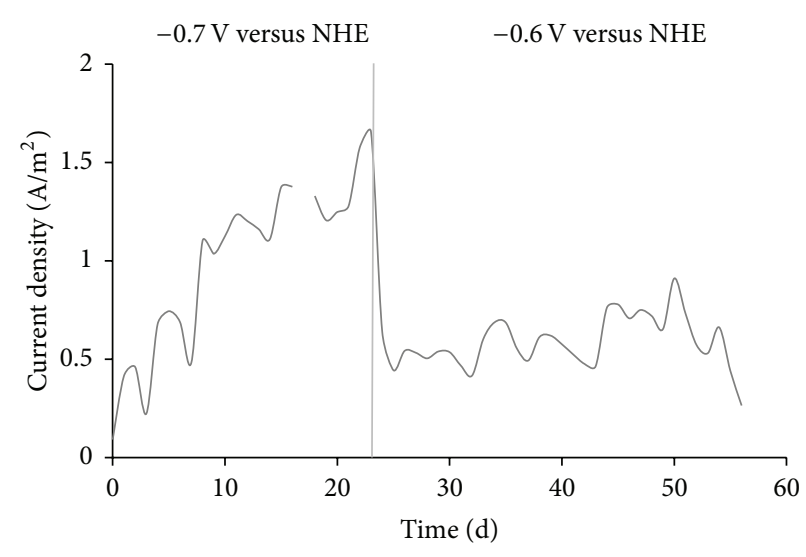

(a)

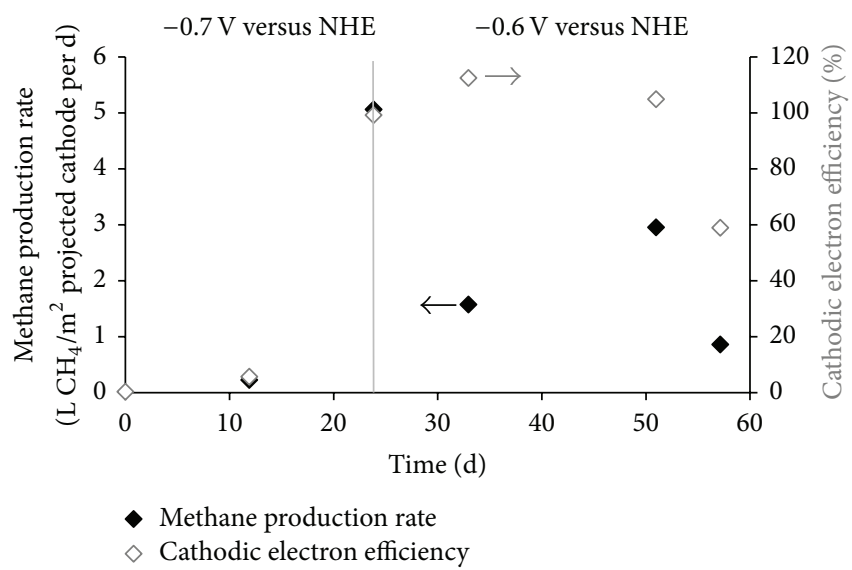

(b)

FIGURE 2: (a) Current density (daily averages) and (b) methane production rate and cathodic electron efficiency with time. Cathode potential was changed from $-0.7 \mathrm{~V}$ versus NHE to $-0.6 \mathrm{~V}$ versus NHE (day 24), as indicated by the grey vertical line.

changed from $-0.7 \mathrm{~V}$ to $-0.6 \mathrm{~V}$ versus NHE. After changing the cathode potential, current density was rather constant, with a daily average of $0.60 \pm 0.16 \mathrm{~A} / \mathrm{m}^{2}$ projected cathode.

Along with electric current consumption, hydrogen and methane were produced at the cathode. On day 12 , only hydrogen $\left(35.7 \% \mathrm{H}_{2}(\mathrm{v} / \mathrm{v})\right)$ was detected in the cathode headspace. On day 24 , only methane was detected in the cathode headspace $\left(29.5 \% \mathrm{CH}_{4}(\mathrm{v} / \mathrm{v})\right)$. Maximum methane production rate was $5.1 \mathrm{~L} \mathrm{CH}_{4} / \mathrm{m}^{2}$ projected cathode per day $\left(119 \mathrm{~mL} \mathrm{CH}_{4} / \mathrm{L}\right.$ reactor per day at standard temperature and pressure, STP) at $-0.7 \mathrm{~V}$ versus NHE cathode potential $\left(1.6 \mathrm{~A} / \mathrm{m}^{2}\right.$, day 24 ; Figure $\left.2(\mathrm{~b})\right)$. Maximum methane production rate was $3.0 \mathrm{~L} \mathrm{CH}_{4} / \mathrm{m}^{2}$ projected cathode per day $\left(69 \mathrm{~mL} \mathrm{CH}_{4} / \mathrm{L}\right.$ reactor per day, at STP) at $-0.6 \mathrm{~V}$ versus NHE cathode potential $\left(0.9 \mathrm{~A} / \mathrm{m}^{2}\right.$, day 51; Figure 2(b)).

Cathodic electron efficiency, the efficiency of capturing the electrons from the electric current in methane, increased from the start of the experiment from $0 \%$ (day 0 ) to $6 \%$ (day 12) to $99 \%$ (day 24 ) at $-0.7 \mathrm{~V}$ versus NHE cathode potential. If the hydrogen produced at day 12 was included, the cathodic electron efficiency would increase to $49 \%$, assuming 4 moles of hydrogen are required per mole of methane. After changing the cathode potential to $-0.6 \mathrm{~V}$ versus NHE, cathodic electron efficiency was $92 \pm 29 \%$ (average of days: 33, 51, and 57) (Figure 2(b)). Cathodic efficiencies of $>100 \%$ have been reported previously [14, 17] and have been explained by biomass degradation and oxidation [17] or oxidation of carbon stored inside the biomass [25].

Reported methane production rates for methane-producing biocathodes in BES are between 0.12 and $24 \mathrm{~L} \mathrm{CH}_{4} / \mathrm{m}^{2}$ projected cathode per day $\left(0.07\right.$ to $\left.15 \mathrm{~A} / \mathrm{m}^{2}\right)$ at $\leq-0.55 \mathrm{~V}$ versus NHE cathode potential (Table 1). The methane production rates and current densities of the biocathode in this study were in the range of reported methane production rates and current densities. Nearly all of the reported studies used undefined enriched or mixed cultures as inoculum for the methane-producing biocathode. In these studies, the microbial populations were not analyzed. Therefore, it is not clear how the microbial community composition affected the performance of the methane-producing biocathode, and via which mechanisms methane was produced. To optimize methane production in BES, key challenges are to select for microorganisms that produce methane at high rate and to operate the BES under their most favorable conditions [18]. This study therefore investigated the microbial community at a methane-producing biocathode and their possible role in bioelectrochemical methane production.

\subsection{Characterization of the Methane-Producing Microbial} Community at the Biocathode. Samples from the biocathode were used to characterize the composition of the microbial community. The microorganisms that were present at the center of the methane-producing biocathode are reported in Table 2. Three phylotypes of archaea and six phylotypes of bacteria were identified in the methane-producing biocathode.

Archaeal 16S rRNA gene sequences were similar to the hydrogen-consuming Methanobacterium palustre strain DSM 3108 (98\%, KC821542 and KC821543) and the hydrogenconsuming Methanobacterium aarhusense strain H2-LR (96\%, KC821541).

Bacterial 16S rRNA gene sequences were similar to Methylocystis sp. SC2 strain SC2 (98\%, KC821549), Acidovorax caeni strain R-24608 or Hydrogenophaga caeni strain EMB71 (98\%, KC821548), Desulfovibrio putealis strain B7-43 (97\%, KC821546), Petrimonas sulfuriphila strain BN3 (96\%, KC821544; 95\%, KC821545), and Ottowia thiooxydans (95\%, KC821547).

3.3. Possible Role of Microorganisms in Bioelectrochemical Methane Production. The methane-producing biocathode analyzed in this study contained three phylotypes of archaea: two phylotypes were closely related to Methanobacterium 


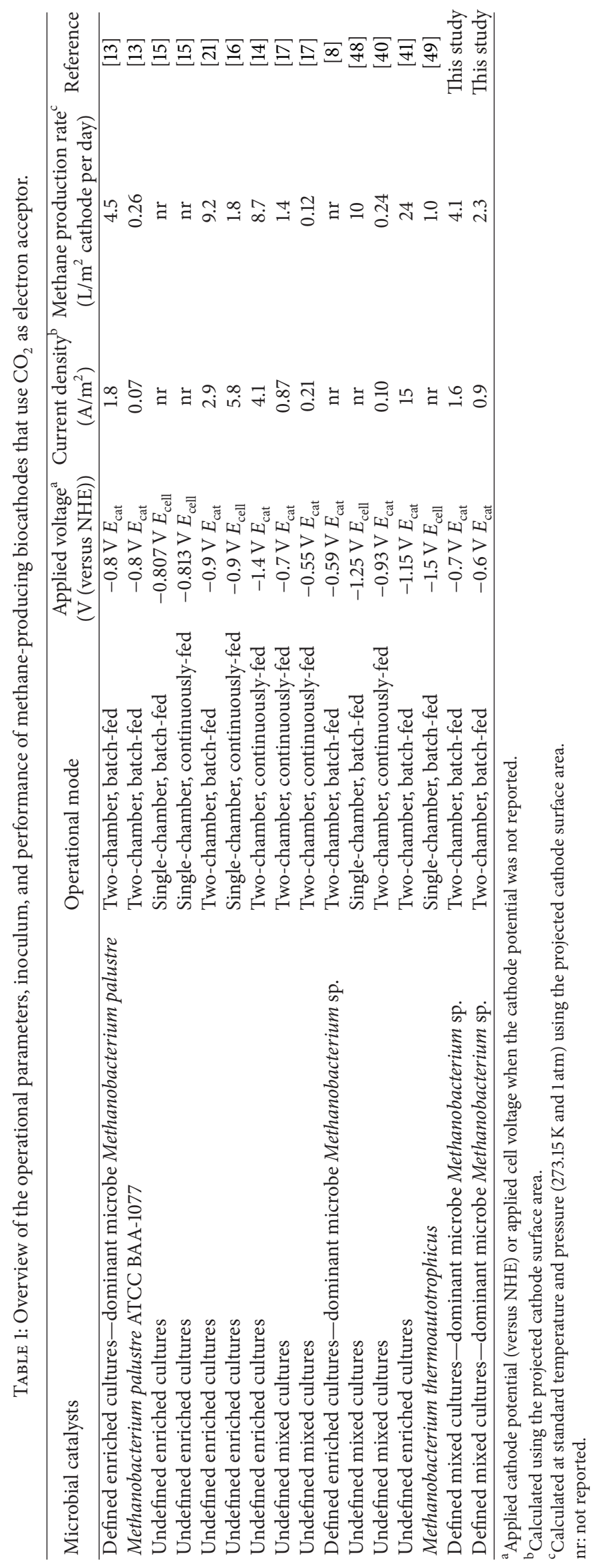




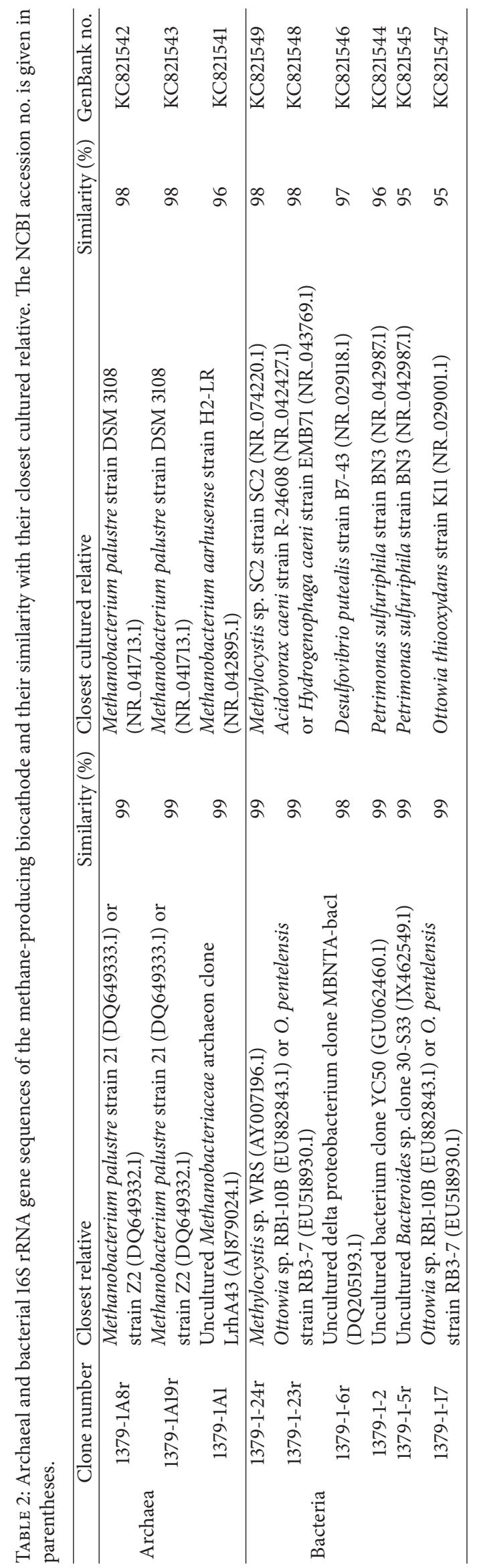


palustre, and the other phylotype was related to Methanobacterium aarhusense. Methanobacterium palustre can use hydrogen as an electron donor [26], although direct use of the electrode as electron donor has also been suggested [13]. Methanobacterium palustre has previously been identified as the dominant microorganism, accounting for $86 \%$ of the total cells, in a mixed-culture methane-producing biocathode inoculated with effluent of a bio-anode that was fed acetate [13]. Methanobacterium aarhusense can only use hydrogen as electron donor [27]. Bioelectrochemical production of hydrogen has been reported previously at the cathode potential used in this study [28]. It is likely that the phylotypes that were closely related to $M$. palustre and $M$. aarhusense used hydrogen as electron donor for bioelectrochemical production of methane. While at the start of the experiment hydrogen was detected in the cathode gas phase, no hydrogen was detected in the cathode gas phase once the biocathode had developed. In the experimental setup, it could not be distinguished whether M. palustre also used the electrode as electron donor.

The methane-producing biocathode contained six phylotypes of bacteria. Bacteria identified in our biocathode that may be associated with bioelectrochemical production of methane were closely related to Desulfovibrio putealis, Hydrogenophaga caeni, and Methylocystis sp.. Desulfovibrio putealis is a strict anaerobic microorganism that is able to use hydrogen, organic acids, or alcohol as an electron donor and sulfate as an electron acceptor [29]. However, it can only grow with hydrogen as electron donor when acetate is provided as carbon source [29]. Several Desulfovibrio sp. are able to catalyze bioelectrochemical hydrogen production at cathode potentials $\leq-0.44 \mathrm{~V}$ versus NHE (e.g., $[2,3])$. In study, the applied cathode potential was $\leq-0.6 \mathrm{~V}$ versus NHE, being in the range of applied potentials at which Desulfovibrio sp. is reported to be electrochemically active. Therefore, we hypothesize that the phylotype that is closely related to $D$. putealis may have produced hydrogen, which in turn could be consumed by the methanogens to produce methane. Future research could focus on bioelectrochemical production of methane by $M$. palustre in the presence and absence of $D$. putealis in order to identify the role of the latter.

Hydrogenophaga caeni is an aerobic microorganism that is able to use hydrogen as an electron donor, however, only when an organic carbon source is provided [30,31]. Hydrogenophaga sp. have also been found at hydrogenproducing biocathodes [32], but their role in hydrogen production remains unclear. The phylotype that is closely related to Hydrogenophaga caeni may have catalyzed hydrogen production or may have been an oxygen scavenger, creating strict anoxic conditions that are essential for the methanogenic archaea.

Methylocystis sp. is a facultative aerobic microorganism that is able to use methane as the sole source of carbon and energy [33]. The phylotype that shows similarity to Methylocystis sp. may have consumed part of the methane, thereby lowering the methane production rate. However, as oxygen scavenger, it will also create the anoxic conditions that are essential for proliferation of methanogenic archaea. Another phylotype that may have been an oxygen scavenger is closely related to Acidovorax caeni. Acidovorax caeni is a facultative aerobic microorganism that is able to use carboxylic acids as carbon source [34]. Oxygen concentrations in the cathode gas phase were $0.6-3.5 \%$. At these oxygen concentrations, aerobic bacteria that may act as oxygen scavengers have a physiological advantage compared to strict anaerobes. This physiological advantage is due to the higher reduction potential of oxygen reduction to water versus, for instance, carbon dioxide reduction to methane, respectively, 1.229 V versus NHE [35] and 0.169 V versus NHE [13] (at STP and $1 \mathrm{M}$ or $1 \mathrm{~atm}$ for all components involved in the reaction).

For some of the bacterial phylotypes, their role in bioelectrochemical methane production remains unclear. For example, Ottowia thiooxydans is a facultative anaerobic microorganism that is able to use nitrate or nitrite for growth and able to oxidize thiosulfate and hydrogen to sulfate [36]. Also, Petrimonas sulfuriphila is a strictly anaerobic microorganism that is able to use sugars as carbon and energy source and able to reduce sulfur with hydrogen to sulfide [37].

In this study, insight is given into the role of the detected community members in methane production. While the identified $16 \mathrm{~S}$ rRNA sequences in our study most likely have similar substrate preferences as their closest relatives, this is not necessarily the case.

After 24 days, the biocathode produced only methane and no hydrogen. This start-up time is similar to reported start-up times for methane-producing biocathodes, that is, 28 days at $-0.59 \mathrm{~V}$ cathode potential [8] and one month at $-0.8 \mathrm{~V}$ cathode potential [13]. 33 days after initiating the methane-producing biocathode, the microbial community of the methane-producing biocathode was investigated (day 57 of the experiment). Although the current density was rather stable after start-up $\left(0.6 \pm 0.15 \mathrm{~A} / \mathrm{m}^{2}\right.$ projected cathode, Figure 2(a)) and only methane was detected, it remains unclear whether a stable microbial community was obtained.

\subsection{Morphology and Distribution of Microorganisms at the} Biocathode. Microscopy techniques were used to give insight into the distribution of the microbial populations at the biocathode. With fluorescence microscopy, the presence of active methanogens in the biocathode can be revealed (Figures 3(a) and $3(\mathrm{~b})$ ). The observed microorganisms were rod-shaped 1$3 \mu \mathrm{m}$ long cells, with a few longer than $5 \mu \mathrm{m}$. The cells were attached to the graphite felt as single cells or as microcolonies (Figures 3(a) and 3(b)). Whereas fluorescence microscopy is generally used to reveal the presence of active methanogens, it should be noted that it may also reveal the presence of reduced cytochromes of bacteria [38].

Scanning electron microscopy (SEM) revealed a variety of rod-shaped microorganisms at the biocathode, varying in their rod form (both straight rods and spiral-shaped rods were observed), the ability to form filaments, and their size (Figures 3(c), 3(d), and 3(e)). The length of the observed rods varied between $<1 \mu \mathrm{m}$ and $10 \mu \mathrm{m}$. The observed rod length was similar to that of the rod-shaped methanogenic archaea pictured by fluorescence microscopy (Figures 3(a) and $3(b))$. No clear relationship was observed between the 


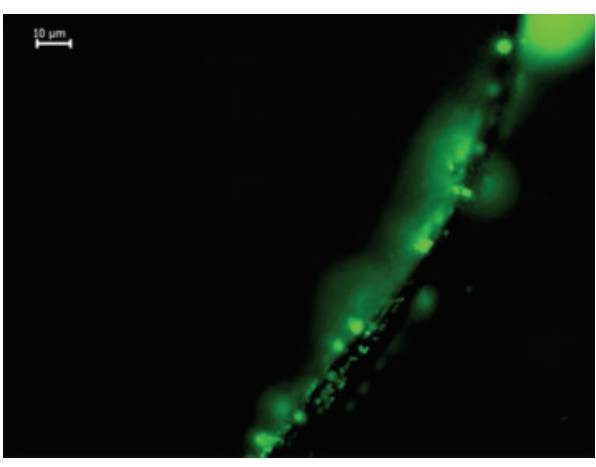

(a)

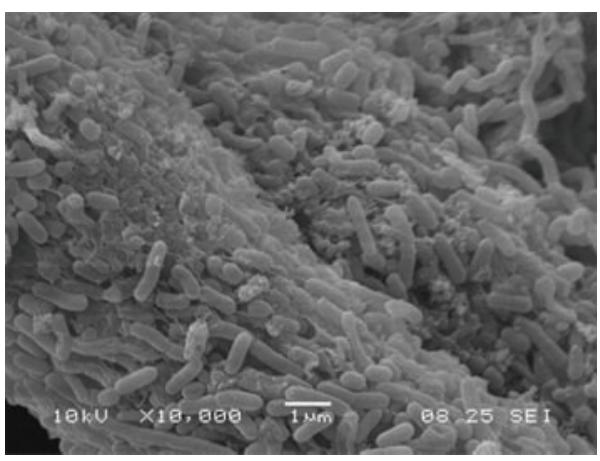

(c)

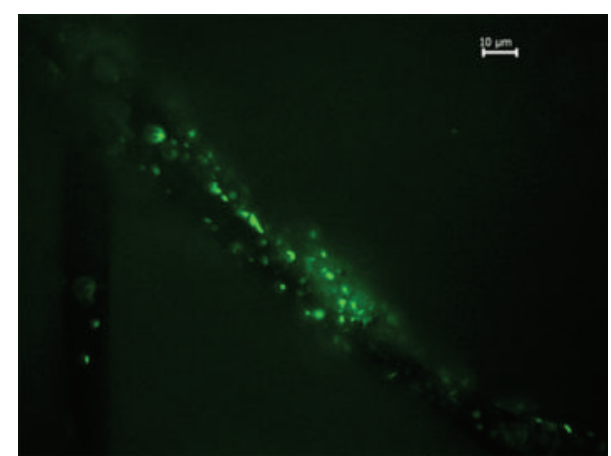

(b)

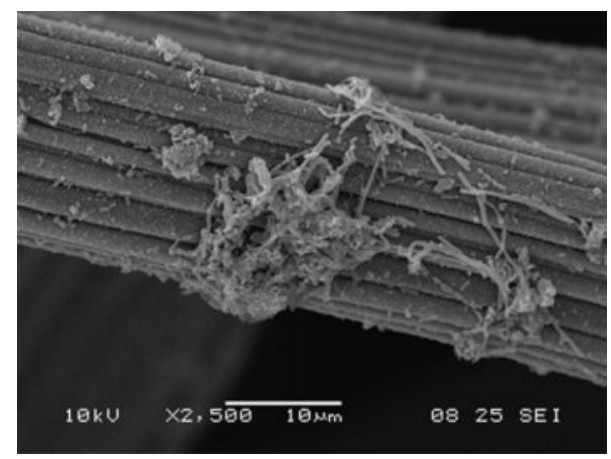

(d)

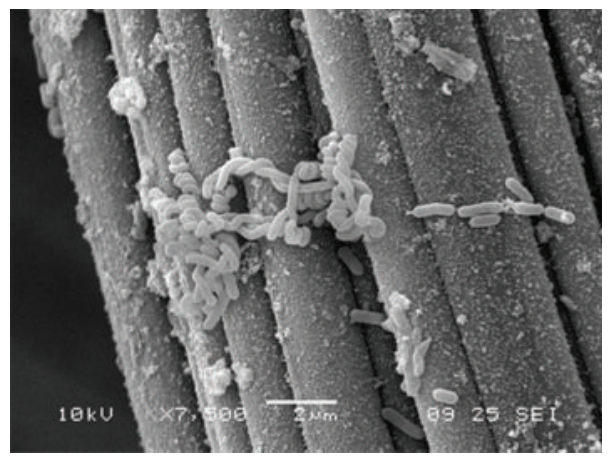

(e)

FIGURE 3: Fluorescence microscopy of the center of the biocathode revealed rod-shaped methanogens that were attached to the graphite felt fibers as single cells ((a) and (b)) or as microcolonies (a). Scanning electron microscopy (SEM) pictures of rod-shaped microorganisms at the center of the biocathode ((c), (d) and (e)). Part of the graphite felt was covered with a dense biofilm (c), while parts were only covered with clusters of microbial cells ((d) and (e)).

morphology and the location within the biocathode. Rodshaped microorganisms varying in size from 1 to $5 \mu \mathrm{m}$ have also been observed in a previous mixed-culture biocathode that simultaneously produced acetate and methane [8].

SEM also revealed that part of the graphite felt was covered with a dense biofilm (Figure 3(c)), while other parts of the graphite felt were only covered with clusters of cells (Figures 3(d) and 3(e)). Both were observed at the low flow zone (where the cathode was located in a dead zone) and the high flow zone (where the cathode was in contact with the straight part of the flow channels). Accumulation of gasses (methane and hydrogen) inside and near the graphite felt electrode may have been an obstacle to attachment, thereby hindering biofilm formation. Another explanation might be that larger cell aggregates, consisting of both anaerobic methanogens and aerobic microorganisms acting as oxygen scavengers, are required to create the strict anoxic conditions needed by the methanogens. The absence of biomass on parts of the electrode could also be explained by a local excess of electron donor (e.g., hydrogen) near the electrode. As long as methanogens have access to electron donors further away from the electrode, there is no need to attach to the electrode and use the electrode as an electron donor.

3.5. Biomass Density at the Methane-Producing Biocathode. Based on the modified Hartree-Lowry analysis, it was found 
that the methane-producing biocathode contained on average $55.6 \pm 11.9 \mathrm{~g} \mathrm{VSS} / \mathrm{m}^{2}$ projected cathode ( $n=6$ samples). This VSS density is in the range of reported VSS densities for bio-anodes, being 8-66 $\mathrm{g} \mathrm{VSS} / \mathrm{m}^{2}$ projected anode surface area [39]. This is the first study to report the VSS density for a methane-producing biocathode. The VSS density and thus the biomass density were similar at different locations of the biocathode: 57 and $68 \mathrm{~g} \mathrm{VSS} / \mathrm{m}^{2}$ projected cathode ( $n=2$ samples) where the catholyte entered the BES, 49 and $65 \mathrm{~g} \mathrm{VSS} / \mathrm{m}^{2}$ projected cathode ( $n=2$ samples) at the center of the biocathode, and 39 and $60 \mathrm{~g} \mathrm{VSS} / \mathrm{m}^{2}$ projected cathode ( $n=2$ samples) where the catholyte left the BES. No clear relationship was observed between biomass density and location at the biocathode. With the current experimental setup, it could not be determined whether all biomass was active. The density of active biomass is an important parameter to improve conversion rates.

3.6. Microbial and Electrochemical Methods to Improve the Performance of a Methane-Producing Biocathode. Methane production rates can be improved by selecting for microorganisms that are involved in methane production or that create the optimal conditions for methane production. Selection strategies that could be used are (i) enrich the inoculum prior to inoculation, (ii) add pure cultures of Methanobacterium palustre and Methanobacterium aarhusense to the mixedculture inoculum to give them a competitive advantage during start-up of the biocathode, (iii) adjust operational conditions to the optimum growth conditions for the preferred microorganisms, and (iv) stimulate the growth of synergistic bacteria that might be involved in bioelectrochemical methane production. Methods to enrich the inoculum prior to inoculation include growing the microbial community with an electrode or hydrogen as electron donor, either in batch experiments with multiple feeding cycles or by using the effluent of well-performing BES [8, 13, 16, 21, 40, 41]. This study shows that the phylotypes that are closely related to Methanobacterium species produce the preferred end product methane. Isolating the Methanobacterium species and testing them as a pure culture would be a first step towards verifying if these methanogens do in fact play a role in methane production at the biocathode as anticipated. Based on these results, enhancement of the number of cells of Methanobacterium species could be a strategy for increasing the methane production rate. Optimizing the operational conditions, such as cathode potential, $\mathrm{pH}$, temperature, and mineral composition of the catholyte are known to positively affect BES performance [18]. Both $M$. palustre and $M$. aarhusense are mesophiles; $M$. palustre has its growth optimum at $37^{\circ} \mathrm{C}(\mathrm{pH} \mathrm{7})$ [26] and $M$. aarhusense at $45^{\circ} \mathrm{C}$ ( $\mathrm{pH} 7.5-8)$ [27]. The temperature and $\mathrm{pH}$ used in this study were thus lower than the optimum conditions for $M$. palustre and $M$. aarhusense. Through adjusting the temperature and $\mathrm{pH}$ to the optimal growth conditions for methanogens, the electrochemically active bacteria as well as bacteria that act as oxygen scavengers, the methane production rates might increase further. Finally, this study revealed that bacteria, such as Desulfovibrio putealis, might be involved in bioelectrochemical methane production through production of hydrogen as intermediate. Synergistic relationships between bacteria and methanogenic archaea were also demonstrated by Cheng and coworkers, who reported that a mixed culture methane-producing biocathode dominated by Methanobacterium palustre performed much better than a pure culture biocathode with Methanobacterium palustre [13]. Stimulating the growth of synergistic bacteria, through either increasing their cell numbers during inoculation or by adjusting the operational conditions, might be viable strategies to further improve bioelectrochemical methane production.

Besides selecting for microorganisms that are involved in methane production, increasing the biomass density could further improve methane production rate. This study shows that the cathode was only partly covered with microorganisms. Likely, increasing the coverage of the cathode with biomass and increasing the biomass density will improve the performance of a methane-producing biocathode [18]. An excess of electron donor (e.g., hydrogen) near the electrode could have made it unnecessary for the methanogens to attach to the electrode. Biomass density can be increased by growing suspended methanogenic biomass on an inert carrier material that is kept in the catholyte. Additionally, biofilm formation could have been hindered due to accumulation of gasses (methane and hydrogen) inside and near the graphite felt electrode. In this study, the catholyte flowed alongside the cathode. Using a flow-through electrode results in improved mass transfer of gasses away from the electrode and substrates towards the electrode [42] and may consequently yield improved biofilm formation. Biomass coverage can also be increased by changing the cathode surface or catholyte composition for improved attachment of the microorganisms. Bacteria in natural systems usually have a net negative charge on the cell surface, resulting in electrostatic repulsion with negative charged surfaces, such as the cathode $[43,44]$. Bacteria are, however, capable of adjusting their cell surface characteristics (charge and hydrophobicity) depending on the environment $[44,45]$. Therefore, prolonged operation might improve bacterial adhesion. Bacterial adhesion could also be improved by changing the properties of the cathode surface, such as the hydrophobicity, and changing the catholyte composition, for example, $\mathrm{pH}$ and conductivity (e.g., $[43,46])$. Another method to improve biomass density on the electrodes would be applying high shear [47]. In addition to improved mass transfer and more effective use of the cathode surface area [42], using a flow-through-electrode results in more compact biocathodes.

\section{Conclusions}

A methane-producing biocathode was obtained that produced methane at a maximum rate of $5.1 \mathrm{~L} \mathrm{CH}_{4} / \mathrm{m}^{2}$ projected cathode per day $\left(1.6 \mathrm{~A} / \mathrm{m}^{2}\right)$ at $-0.7 \mathrm{~V}$ versus $\mathrm{NHE}$ cathode potential and $3.0 \mathrm{~L} \mathrm{CH}_{4} / \mathrm{m}^{2}$ projected cathode per day $\left(0.9 \mathrm{~A} / \mathrm{m}^{2}\right)$ at $-0.6 \mathrm{~V}$ versus NHE cathode potential. The microbial community at the methane-producing biocathode 
was dominated by three phylotypes of archaea and six phylotypes of bacteria. The archaeal phylotypes were most closely related to Methanobacterium palustre and Methanobacterium aarhusense. This study shows that, besides methanogenic archaea, bacteria may support methane production through production of hydrogen as intermediate or oxygen scavenging.

\section{Conflict of Interests}

The authors have no direct financial relation with the commercial identities mentioned in the paper that might lead to a conflict of interests.

\section{Acknowledgments}

The authors thank Bert Hamelers for the fruitful discussions, Astrid Paulitsch-Fuchs and Arie Zwijnenburg for their help with scanning electron microscopy, Martin Liebensteiner for his help with autofluorescence microscopy, Christel Kampman for her help with the Hartree-Lowry protein analysis, and Nora Sutton for her help with submitting the rRNA sequences to Genbank and correcting the paper.

\section{References}

[1] R. Emde and B. Schink, "Enhanced propionate formation by Propionibacterium freudenreichii subsp. freudenreichii in a three-electrode amperometric culture system," Applied and Environmental Microbiology, vol. 56, no. 9, pp. 2771-2776, 1990.

[2] F. Aulenta, L. Catapano, L. Snip, M. Villano, and M. Majone, "Linking bacterial metabolism to graphite cathodes: electrochemical insights into the $\mathrm{H}_{2}$-producing capability of Desulfovibrio sp.", ChemSusChem, vol. 5, no. 6, pp. 1080-1085, 2012.

[3] E. Croese, M. A. Pereira, G.-J. W. Euverink, A. J. M. Stams, and J. S. Geelhoed, "Analysis of the microbial community of the biocathode of a hydrogen-producing microbial electrolysis cell," Applied Microbiology and Biotechnology, vol. 92, no. 5, pp. 10831093, 2011.

[4] R. A. Rozendal, H. V. M. Hamelers, G. J. W. Euverink, S. J. Metz, and C. J. N. Buisman, "Principle and perspectives of hydrogen production through biocatalyzed electrolysis," International Journal of Hydrogen Energy, vol. 31, no. 12, pp. 1632-1640, 2006.

[5] R. A. Rozendal, E. Leone, J. Keller, and K. Rabaey, "Efficient hydrogen peroxide generation from organic matter in a bioelectrochemical system," Electrochemistry Communications, vol. 11, no. 9, pp. 1752-1755, 2009.

[6] K. Rabaey, S. Bützer, S. Brown, J. Keller, and R. A. Rozendal, "High current generation coupled to caustic production using a lamellar bioelectrochemical system," Environmental Science and Technology, vol. 44, no. 11, pp. 4315-4321, 2010.

[7] K. P. Nevin, T. L. Woodard, A. E. Franks, Z. M. Summers, and D. R. Lovley, "Microbial electrosynthesis: feeding microbes electricity to convert carbon dioxide and water to multicarbon extracellular organic compounds," mBio, vol. 1, no. 2, 2010.

[8] C. W. Marshall, D. E. Ross, E. B. Fichot, R. S. Norman, and H. D. May, "Electrosynthesis of commodity chemicals by an autotrophic microbial community," Applied and Environmental Microbiology, vol. 78, no. 23, pp. 8412-8420, 2012.
[9] K. J. J. Steinbusch, H. V. M. Hamelers, J. D. Schaap, C. Kampman, and C. J. N. Buisman, "Bioelectrochemical ethanol production through mediated acetate reduction by mixed cultures," Environmental Science and Technology, vol. 44, no. 1, pp. 513-517, 2010.

[10] P. Kuntke, K. M. Śmiech, H. Bruning et al., "Ammonium recovery and energy production from urine by a microbial fuel cell," Water Research, vol. 46, no. 8, pp. 2627-2636, 2012.

[11] O. Choi, Y. Um, and B.-I. Sang, "Butyrate production enhancement by Clostridium tyrobutyricum using electron mediators and a cathodic electron donor," Biotechnology and Bioengineering, vol. 109, no. 10, pp. 2494-2502, 2012.

[12] M. C. A. A. van Eerten-Jansen, A. ter Heijne, T. I. M. Grootscholten et al., "Bioelectrochemical production of caproate and caprylate from acetate by mixed cultures," Sustainable Chemistry and Engineering, vol. 1, no. 5, pp. 513-518, 2013.

[13] S. Cheng, D. Xing, D. F. Call, and B. E. Logan, "Direct biological conversion of electrical current into methane by electromethanogenesis," Environmental Science and Technology, vol. 43, no. 10, pp. 3953-3958, 2009.

[14] K. Y. Cheng, G. Ho, and R. Cord-Ruwisch, "Novel methanogenic rotatable bioelectrochemical system operated with polarity inversion," Environmental Science and Technology, vol. 45, no. 2, pp. 796-802, 2011.

[15] P. Clauwaert and W. Verstraete, "Methanogenesis in membraneless microbial electrolysis cells," Applied Microbiology and Biotechnology, vol. 82, no. 5, pp. 829-836, 2009.

[16] G. K. Rader and B. E. Logan, "Multi-electrode continuous flow microbial electrolysis cell for biogas production from acetate," International Journal of Hydrogen Energy, vol. 35, no. 17, pp. 8848-8854, 2010.

[17] M. C. A. A. van Eerten-Jansen, A. ter Heijne, C. J. N. Buisman, and H. V. M. Hamelers, "Microbial electrolysis cells for production of methane from $\mathrm{CO}_{2}$ : long-term performance and perspectives," International Journal of Energy Research, vol. 36, no. 6, pp. 809-819, 2012.

[18] P. Clauwaert, P. Aelterman, T. H. Pham et al., "Minimizing losses in bio-electrochemical systems: the road to applications," Applied Microbiology and Biotechnology, vol. 79, no. 6, pp. 901913, 2008.

[19] A. ter Heijne, H. V. M. Hamelers, V. De Wilde, R. A. Rozendal, and C. J. N. Buisman, "A bipolar membrane combined with ferric iron reduction as an efficient cathode system in microbial fuel cells," Environmental Science and Technology, vol. 40, no. 17, pp. 5200-5205, 2006.

[20] A. ter Heijne, H. V. M. Hamelers, M. Saakes, and C. J. N. Buisman, "Performance of non-porous graphite and titaniumbased anodes in microbial fuel cells," Electrochimica Acta, vol. 53, no. 18, pp. 5697-5703, 2008.

[21] M. Villano, F. Aulenta, C. Ciucci, T. Ferri, A. Giuliano, and M. Majone, "Bioelectrochemical reduction of $\mathrm{CO}_{2}$ to $\mathrm{CH}_{4}$ via direct and indirect extracellular electron transfer by a hydrogenophilic methanogenic culture," Bioresource Technology, vol. 101, no. 9, pp. 3085-3090, 2010.

[22] R. A. Rozendal, H. V. M. Hamelers, R. J. Molenkamp, and C. J. N. Buisman, "Performance of single chamber biocatalyzed electrolysis with different types of ion exchange membranes," Water Research, vol. 41, no. 9, pp. 1984-1994, 2007.

[23] M. T. Suzuki and S. J. Giovannoni, "Bias caused by template annealing in the amplification of mixtures of $16 \mathrm{~S}$ rRNA genes 
by PCR," Applied and Environmental Microbiology, vol. 62, no. 2, pp. 625-630, 1996.

[24] T. Lueders and M. Friedrich, "Archaeal population dynamics during sequential reduction processes in rice field soil," Applied and Environmental Microbiology, vol. 66, no. 7, pp. 2732-2742, 2000.

[25] S. Freguia, K. Rabaey, Z. Yuan, and J. Keller, "Electron and carbon balances in microbial fuel cells reveal temporary bacterial storage behavior during electricity generation," Environmental Science and Technology, vol. 41, no. 8, pp. 2915-2921, 2007.

[26] G. Zellner, K. Bleicher, E. Braun et al., "Characterization of a new mesophilic, secondary alcohol-utilizing methanogen, Methanobacterium palustre spec. nov. from a peat bog," Archives of Microbiology, vol. 151, no. 1, pp. 1-9, 1988.

[27] A. G. Shlimon, M. W. Friedrich, H. Niemann, N. B. Ramsing, and K. Finster, "Methanobacterium aarhusense sp. nov., a novel methanogen isolated from a marine sediment (Aarhus Bay, Denmark)," International Journal of Systematic and Evolutionary Microbiology, vol. 54, no. 3, pp. 759-763, 2004.

[28] R. A. Rozendal, A. W. Jeremiasse, H. V. M. Hamelers, and C. J. N. Buisman, "Hydrogen production with a microbial biocathode," Environmental Science and Technology, vol. 42, no. 2, pp. 629634, 2008.

[29] O. Basso, P. Caumette, and M. Magot, "Desulfovibrio putealis sp. nov., a novel sulfate-reducing bacterium isolated from a deep subsurface aquifer," International Journal of Systematic and Evolutionary Microbiology, vol. 55, no. 1, pp. 101-104, 2005.

[30] B. S. Chung, S. H. Ryu, M. Park, Y. Jeon, Y. R. Chung, and C. O. Jeon, "Hydrogenophaga caeni sp. nov., isolated from activated sludge," International Journal of Systematic and Evolutionary Microbiology, vol. 57, no. 5, pp. 1126-1130, 2007.

[31] A. Willems, J. Busse, M. Goor et al., "Hydrogenophaga, a new genus of hydrogen-oxidizing bacteria that includes Hydrogenophaga flava comb. nov. (formerly Pseudomonas flava), Hydrogenophaga palleronii (formerly Pseudomonas palleronii), Hydrogenophaga pseudoflava (formerly Pseudomonas pseudoflava and "Pseudomonas carboxydoflava"), and Hydrogenophaga taeniospiralis (formerly Pseudomonas taeniospiralis)," International Journal of Systematic Bacteriology, vol. 39, no. 3, pp. 319333, 1989.

[32] E. Croese, Ecophysiology of Microorganisms in Microbial Electrolysis Cells, Wageningen University, 2012.

[33] B. Dam, S. Dam, M. Kube, R. Reinhardt, and W. Liesack, "Complete genome sequence of Methylocystis sp. strain SC2, an aerobic methanotroph with high-affinity methane oxidation potential," Journal of Bacteriology, vol. 194, no. 21, pp. 60086009, 2012.

[34] K. Heylen, L. Lebbe, and P. de Vos, “Acidovorax caeni sp. nov., a denitrifying species with genetically diverse isolates from activated sludge," International Journal of Systematic and Evolutionary Microbiology, vol. 58, no. 1, pp. 73-77, 2008.

[35] B. E. Logan, B. Hamelers, R. Rozendal et al., "Microbial fuel cells: methodology and technology," Environmental Science and Technology, vol. 40, no. 17, pp. 5181-5192, 2006.

[36] S. Spring, U. Jäckel, M. Wagner, and P. Kämpfer, "Ottowia thiooxydans gen. nov., sp. nov., a novel facultatively anaerobic, $\mathrm{N}_{2} \mathrm{O}$-producing bacterium isolated from activated sludge, and transfer of Aquaspirillum gracile to Hylemonella gracilis gen. nov., comb. nov," International Journal of Systematic and Evolutionary Microbiology, vol. 54, no. 1, pp. 99-106, 2004.

[37] A. Grabowski, B. J. Tindall, V. Bardin, D. Blanchet, and C. Jeanthon, "Petrimonas sulfuriphila gen. nov., sp. nov., a mesophilic fermentative bacterium isolated from a biodegraded oil reservoir," International Journal of Systematic and Evolutionary Microbiology, vol. 55, no. 3, pp. 1113-1121, 2005.

[38] A. Esteve-Núñez, J. Sosnik, P. Visconti, and D. R. Lovley, "Fluorescent properties of $c$-type cytochromes reveal their potential role as an extracytoplasmic electron sink in Geobacter sulfurreducens," Environmental Microbiology, vol. 10, no. 2, pp. 497-505, 2008.

[39] G. Liu, M. D. Yates, S. Cheng, D. F. Call, D. Sun, and B. E. Logan, "Examination of microbial fuel cell start-up times with domestic wastewater and additional amendments," Bioresource Technology, vol. 102, no. 15, pp. 7301-7306, 2011.

[40] M. Villano, S. Scardala, F. Aulenta, and M. Majone, "Carbon and nitrogen removal and enhanced methane production in a microbial electrolysis cell," Bioresource Technology, vol. 130, pp. 366-371, 2013.

[41] Y. Jiang, M. Su, Y. Zhang, G. Zhan, Y. Tao, and D. Li, "Bioelectrochemical systems for simultaneously production of methane and acetate from carbon dioxide at relatively high rate," International Journal of Hydrogen Energy, vol. 38, no. 8, pp. 3497-3502, 2013.

[42] T. H. J. A. Sleutels, R. Lodder, H. V. M. Hamelers, and C. J. N. Buisman, "Improved performance of porous bio-anodes in microbial electrolysis cells by enhancing mass and charge transport," International Journal of Hydrogen Energy, vol. 34, no. 24, pp. 9655-9661, 2009.

[43] M. C. M. Van Loosdrecht, J. Lyklema, W. Norde, and A. J. B. Zehnder, "Bacterial adhesion: a physiochemical approach," Microbial Ecology, vol. 17, no. 1, pp. 1-15, 1989.

[44] H. J. Busscher and A. H. Weerkamp, "Specific and non-specific interactions in bacterial adhesion to solid substrata," FEMS Microbiology Letters, vol. 46, no. 2, pp. 165-173, 1987.

[45] K. C. Marshall, R. Stout, and R. Mitchell, "Selective sorption of bacteria from seawater," Canadian Journal of Microbiology, vol. 17, no. 11, pp. 1413-1416, 1971.

[46] H. H. M. Rijnaarts, W. Norde, E. J. Bouwer, J. Lyklema, and A. J. B. Zehnder, "Reversibility and mechanism of bacterial adhesion," Colloids and Surfaces B, vol. 4, no. 1, pp. 5-22, 1995.

[47] M. S. Powell and N. K. H. Slater, "Removal rates of bacterial cells from glass surfaces by fluid shear," Biotechnology and Bioengineering, vol. 24, no. 11, pp. 2527-2537, 1982.

[48] H. Kobayashi, N. Saito, Q. Fu et al., "Bio-electrochemical property and phylogenetic diversity of microbial communities associated with bioelectrodes of an electromethanogenic reactor," Journal of Bioscience and Bioengineering, vol. 116, no. 1, pp. 114-117, 2013.

[49] K. Sato, H. Kawaguchi, and H. Kobayashi, "Bio-electrochemical conversion of carbon dioxide to methane in geological storage reservoirs," Energy Conversion and Management, vol. 66, pp. 343-350, 2013. 

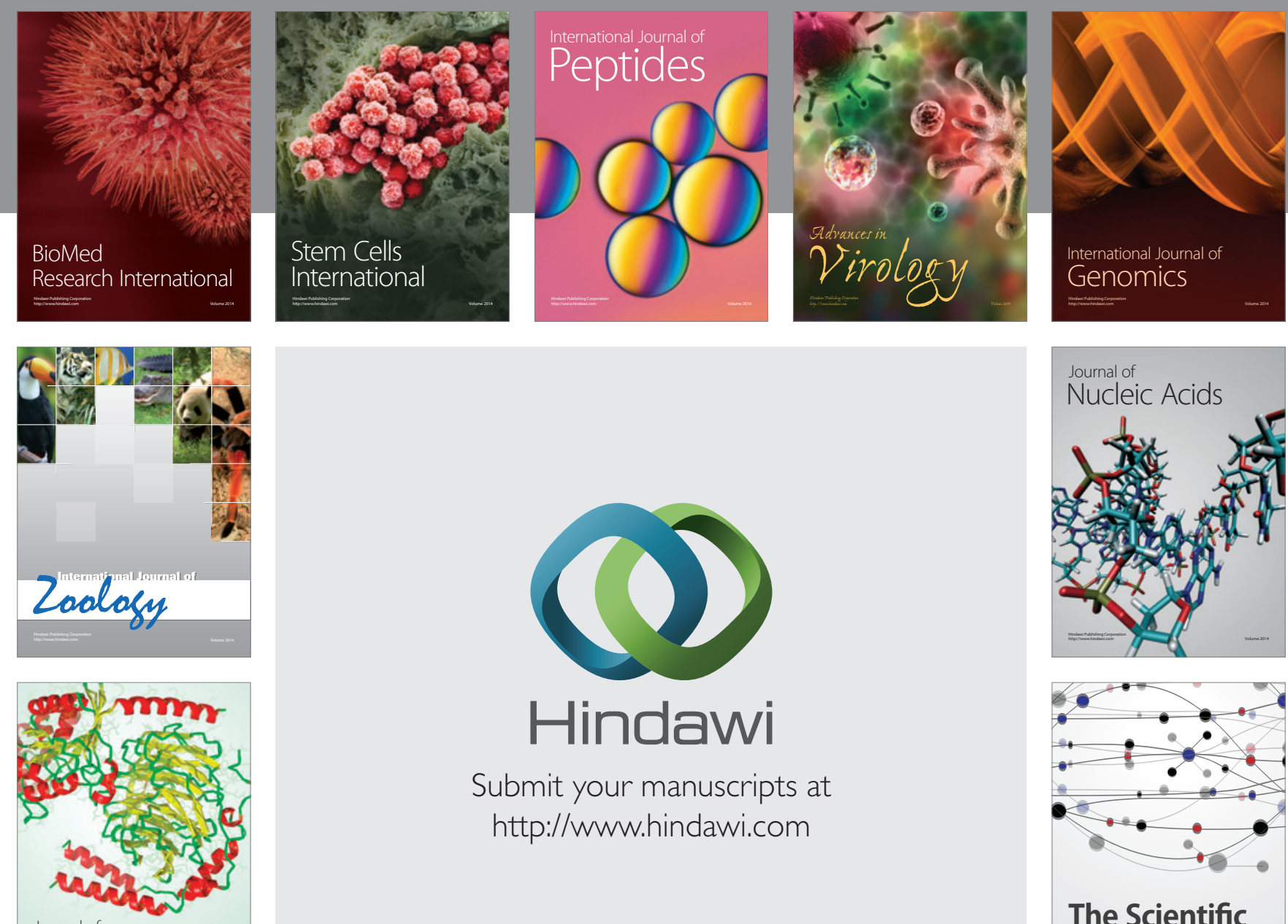

Submit your manuscripts at

http://www.hindawi.com

Journal of
Signal Transduction
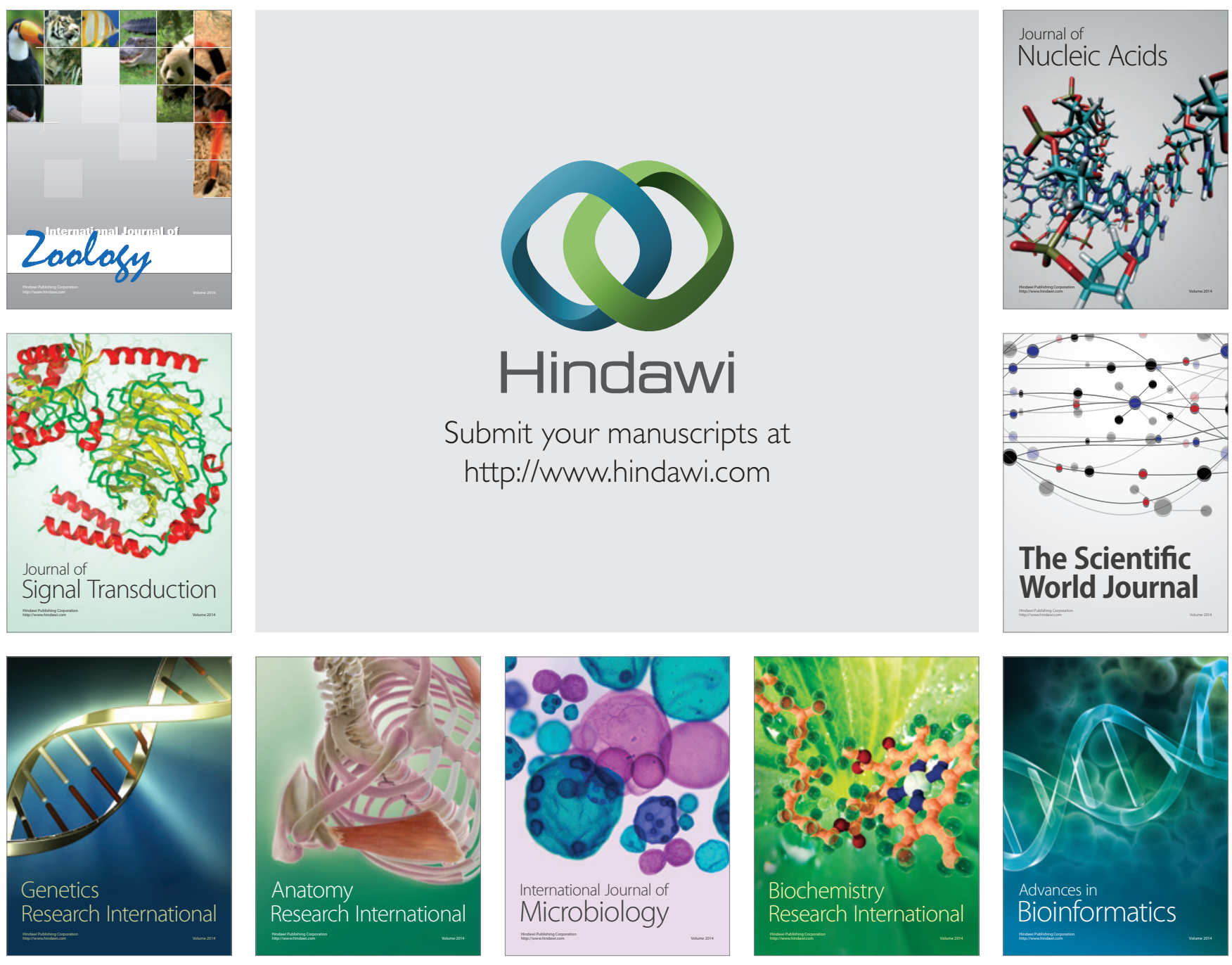

The Scientific World Journal
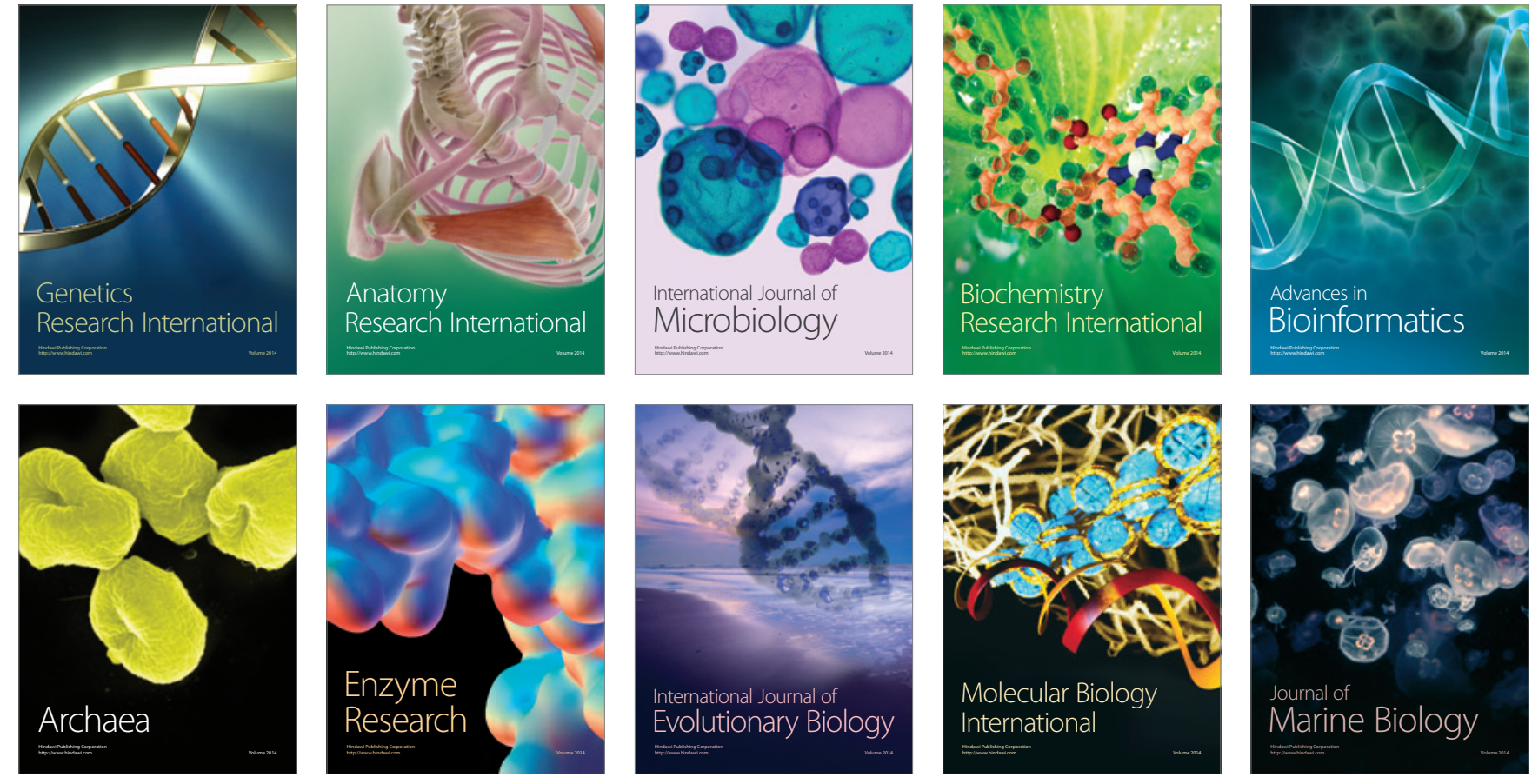